\title{
Climatic Peculiarities as the Earth Heritage Elements of Serbia
}

\section{Radovanović, Milan' Mijović, Dušan²}

\begin{abstract}
Theoretically, each point on the Earth, relative to the regional atmospheric circulation and geodiversity, has a particular type of climate; therefore, any conclusion on regional climate calls for some generalization. For a basic notion of the climatic peculiarities of Serbia, it would be sufficient to begin with its extreme and apply some statistics.

The results and the analysis of morphological features of areas and their climatic peculiarities are used in selecting the Earth heritage sites for a unified inventory.
\end{abstract}

Key words: climate, peculiarities, Earth heritage, Serbia.

\section{${ }^{1}$ Milan Radovanović}

Geographical Institute "Jovan Cvijić" of Serbian Academy of Sciences and Arts, 9 Đure Jakšića, 11000 Belgrade, Serbia, rmilan@net.yu,

\section{Dušan Mijović}

Nature Conservation Institute of Serbia, 11000 Belgrade, Serbia,

miyo@eunet.yu

\section{Introduction}

The Earth heritage sites in Europe have been selected and protected for more than ten years using a unified methodology designed by ProGEO, the European Association for Conservation of the Geological Heritage. Diverse sites under different earth science disciplines are classified as the following types of sites (defined in points 2 and 3 ):

"Paleoenvironmental - past climate, global sedimentary geology, fossil indicators, sedimentary events and processes (C).

"Paleobiological - macro - and micro - animals and plants, problematic traces, stromatolites, evaluation (A)".

Basically, in geology and other earth sciences geological structure and its formation is studied. Therefore one should remember the evolution of geological processes which are still in progress. One of essential factors of modern processes, defined as exogenetic forces, is the climate of an area. It follows from the above stated that climate characteristics should be an element of consideration for a geo-heritage site selection. Among numerous climate characteristics, only peculiar ones are selected for consideration, referred to as climatic peculiarities.

\section{Material and Methods}

The term climatic peculiarities is not uniformly applicable to any region, because it is not clearly defined. Its use differs in relation to climatic elements and to the area studied.

One of major problems is the magnitude of threshold of a climatic element. If it were too low, the number of observation points would be "large" and obscure as to the peculiarity. On the other hand, there is not a generally accepted criterion for the selection $^{1}$ of thresholds in this kind of research.

Besides, there is not a universal standard for denotation of the symbols used in the attached map. In this attempt of a pioneer, the categorization of the used indicators is notably subjective.

\footnotetext{
Armand (1955) writes: "The scale of values is se lected in ranges that should express quantitative limits of particular practical values, the scale should use rounded figures". The term "particular" value seems to be broad and definitely vague for some purposes (our note).
}

For the purposes of this paper, analytical results are used for air temperature (78), precipitation (910), air pressure (20), and wind (29 stations) in Serbia (Radovanović, 2001). Following the recommendation of the World Meteorological Organization (WMO), that climate of an area is preferably studied using data for thirty - year long sequence, we used the period 1961 - 1990 for most of climatic elements (excluding wind).

For wind, data are considered representative if covering a period of at least fifteen years; therefore, wind frequencies and velocities data are borrowed from and partly processed by Janković - Golubović (1992) and refer to the interval 1949 - 1980. Because average wind frequencies and velocities variability depends on the observed period of time, and because the ranges of processed numerical data partly overlap with other analyzed elements, it has been decided to apply the published results of the mentioned authors.

For air temperature, the criterion used for absolute negative extremes, which fall down to $-30^{\circ} \mathrm{C}$. Areas with these conditions prevailing are regarded as "coldness poles" (Rakićević, 1971). On the other hand, "warmness poles" were also identified, considering critical temperatures those exceeding $40^{\circ} \mathrm{C}$. These high temperatures seldom occurred in the given period (1961 - 1990), but common occurrence of these temperatures in the last decade of $2 \mathrm{O}^{\text {th }}$ century calls for the correction of the critical threshold.

Also the dispersion of data for average air temperatures is considered. Thus, locations of standard deviations $(\sigma)$ greater than $3^{\circ} \mathrm{C}$ are taken into account. This high standard deviation in Europe is registered only in Scandinavia (Collective authorship, 1985). Places where $\sigma$ falls below $1^{\circ} \mathrm{C}$ are shown on the map as well.

As to the continentality rate, based on thermodrome coefficient, places of notable continentality (below -3\%) are mapped, as well as those of high maritimity (over 15\%).

Temperature amplitudes are used to identify places of transitional maritimity $\left(19^{\circ} \mathrm{C} \geq \mathrm{A} \leq 20^{\circ} \mathrm{C}\right)$ and those of maritime type $\left(19^{\circ} \mathrm{C} \leq \mathrm{A}\right)$. Other stations in Serbia are in places of increased continentality.

For precipitation, a boundary is located between two different pluviometric regimes, 
or areas are determined where rainfall maxima occur in different periods of the year.

For instance, where average amounts of precipitation in the cold period of the year were higher (more than $50 \%$ ) than those in the warm period, the regime is considered maritime (Vujević, 1936). These differences can be observed by seasons; when precipitations are higher in summer than in winter (or autumn, depending on the region), the pluviometric regime is called continental (Vujević, 1955). The analyzed data demonstrate that precipitation is the highest in most of the stations in May and June or in November and December. The pluviometric regime is determined through the application of the mentioned approach. Rainfall regime of each area is determined according to the time of the highest precipitation. The analysis of the lowest precipitations renders a complicated pattern, which is not considered in this paper. The given map shows that maritimity by the rainfall regime is prevailing only in the southwest of the country. Similar situation is identified in nine more localities besides this compact area.

Only pluviometric stations with continuous records of at least twenty-year period are taken into consideration.

Coefficient of variation, such as standard deviation, gives the average measurement data dispersion in relation to the average values. Particular consideration is given to the main stations where $\mathrm{C}_{\mathrm{v}}$ was higher than $100 \%$ and those where this parameter was lower than $35 \%$. The consideration of all observation points would give a too dense network of points, or the threshold of the mentioned criterion would have to be corrected.

The analysis of data from 23 major meteorological stations, by Abbe criterion showed that twelve places had homogeneous series for temperature data, six for rainfall, and only two (Kragujevac and Priština) for both rainfall and air temperature series (Smailagić and Janković, 1992). Data from other stations are not tested.

Only a minor part of northeastern Serbia had mean annual air pressure of more than $1010 \mathrm{mb}$, or the highest registered pressure. The quantities are reduced to $o^{\circ} \mathrm{C}$, but not to the sea level, because the air pressure reduction to the sea level is used to avoid the influence of topography on the obtained quantities. Also, the line mark of the annual air pressure approaches $800 \mathrm{mb}$.

Wind velocities exceeding $4 \mathrm{~m} / \mathrm{s}$ are considered, regardless the wind direction or the season of the year. Furthermore calm air indicators are considered, and $400 \%$ is taken as the lowest limit. Frequencies of winds from some directions are not considered.

\section{Analysis of Climatic Data}

The available data reveal that seventeen stations register absolute negative temperature extremes below $-30^{\circ} \mathrm{C}$, eight of which are situated in Vojvodina, the province characterized by lakes of cold air strata Notably low temperatures occur in some depressions on the peripannonian margin, but they may be caused by flowing of cold air from the mountains at the back. Cold air may be the result of an inrush of continental of artic air mass, or influenced by mountains. Earlier researchers (Rakićević, 1971) mention only four "coldness poles": Sjenica, Homolje, Vršac and Vlasina. This number of poles seems to be much higher in Serbia, which indicates that the preceding period could have been warmer. The absolute minimum $\left(-35.6^{\circ} \mathrm{C}\right)$ for Serbia was registered on 13 January 1985 at Sjenica, situated on a highland plateau (1038 $\mathrm{m}$ a.s.l.) with combined effects of the northern cold air - mass and the flow of cooled heavier air layers from the surrounding mountains. Similar situation is noted on Vlasina, and in other places with similar land morphology.

Absolute air temperature extremes of over $40^{\circ} \mathrm{C}$ have been registered in a greater number of stations (29). Like the low extremes, these are not frequent, but unlike the latter, maximum air temperatures always occur in lowlands. Extremely high temperatures are registered only three times at altitudes over $500 \mathrm{~m}$, all three in the last five years. The absolute maximum of $42.3^{\circ} \mathrm{C}$ was registered on 25 July in Niš.

A standard deviation of more than $3^{\circ} \mathrm{C}$ on average always occurs in winter, most frequently in Vojvodina and less on the peripannonian margin (total 15 stations). The extensive lowland of northern Serbia (Vojvodina) has a relatively frequent alternation of cold and warm air masses over its territory in winter; consequently, the temperature point dispersion in relation to the average temperature is the greatest in this province in the mentioned season of the year.

Standard deviation below $1^{\circ} \mathrm{C}$ is recorded in the summer period. This seems to be the result of many factors, as recorded in nineteen places from Bački Petrovac (alt. $85 \mathrm{~m}$ a.s.l.) to Bele Vode on Golija Mt (1500 $\mathrm{m}$ a.s.l.). For the determination of the dominant factor, each of the nineteen localities ought to be studied.

Only Metohian stations, Đakovica, Dragaš, Istok, Klina, Prizren, have secondary maxima of standard deviations in May. Standard deviations for Pec and Kosovska Mitrovica, northern Kosovo, are equal in April and May. Besides Kosovo, only Bela Crkva, Čačak, Senta and Vranje have equal standard deviation in April and May. The highest mountain of Serbia (Prokletije $2656 \mathrm{~m}$ a.s.l.) certainly controls air circulation in the nearest depression at altitudes below $400 \mathrm{~m}$. The air in the depression gets heated in late spring when it is still cold on the surrounding mountains.
The obtained data can be interpreted as the results of an intensive exchange of hot and cold air masses.

The lowest thermodrome coefficients, below $-3 \%$, are obtained for low areas of the Valachian - Pontian basin (Knjaževac, Negotin, Zaječar). The Carpathian - Balkan massif arc rises in western background of this part of Serbia controlling the regional atmospheric circulation.

In contrast, maritime regime is present (above $15 \%$ ) only at the highest station (1711 $\mathrm{m}$ a.s.l.) on Kopaonik. At most of the stations, the temperature range from the warmest to the coldest months is quite small.

Continental and maritime pluviometric regimes can be defined also by using mean monthly air temperatures. Stations where the maritime climate prevails are Bele Vode on Golija Mt., Dragaš, Kopaonik, and Mitrovac on Tara Mt., or generally most of the stations at altitudes over $1000 \mathrm{~m}$. The transitional type of climate is also dominant on high mountains: $\mathrm{Ku}-$ kavica and Zlatibor, but also on somewhat lower altitudes: Rudnik, and Sijarinska Banja $(455 \mathrm{~m})$. For the last mentioned station, either incorrect data are assumed, or it has a peculiar local climate.

Besides standard deviations of mean monthly air temperatures, Metohia is the only region of Serbia where the maritime pluviometric regime is prevailing (excluding Prizrenska Bistrica basin in the farthest southeast). Maritime regime prevails in western Kosovo, primarily controlled by a lower watershed between the two regions. Maritime regime is also registered at stations marked on the map. Brodarevo and Goševo stations are in the Lim valley through which wet air masses move from Montenegro into southwestern Serbia. Further northwards in the same valley, continental regime is prevailing. Stations in the maritime regime are located in the Južna Morava valley and in southeastern Serbia, probably directly influenced by cy clones that move four or five times annually from the Adriatic coast to the Black Sea (Barry and Chorley 1992). The mentioned penetration of air masses to Kosovo and Metohia seem to confront continental air masses, rise above them, and influence local climate only in several places.

In the part of Serbia represented by Gradskovo station, the dominant influence of air masses is questionable: either it is the one towards or the one from the Black Sea. Data from the earlier period $(1931-1960)$ indicate to some extent larger area of maritime regime in eastern Serbia (Rakićević, 1976, 1979, 1988;)

Dispersion of rainfall points for most of the stations is the smallest in June, April and November. Minimum $\mathrm{C}_{\mathrm{v}}$ occurs in one of these months at 70 out of 78 stations. 
It is usually sufficient to have much higher than average rainfall in one or two months of the thirty-year series to affect the variation. In some instances, rainfalls are "uniform" within a month period, without any occurrences of storms. For example, the precipitation in Belgrade was $184.9 \mathrm{~mm}$ for October 1974, while the maximum was $37.4 \mathrm{~mm}$ (14 Oct.). Average rainfall for October was $40.3 \mathrm{~mm}$, or over 4.5 times less than in the given example. Only in October 1972 fell more than $100 \mathrm{~mm}$ of rain, which raised $\mathrm{Cv}$ for over $100 \%$. The situation was similar in most of Belgrade and many other stations.

The highest mean annual air pressures occur in the areas at low altitudes also the farthest from the Adriatic Sea. One of typical examples is the area of Negotin. Low pressures, below $800 \mathrm{mb}$, prevail on high ridges and peaks at altitudes over $2000 \mathrm{~m}$.

High wind velocities (over $4 \mathrm{~m} / \mathrm{s}$ ) are recorded for Kopaonik (1711 m a.s.l.), which is logical, because wind frequency and strength grow with the altitude and calm air intervals are less frequent. Average wind velocities over $4 \mathrm{~m} / \mathrm{s}$ are registered only in Vršac (83 $\mathrm{m}$ a.s.l.), where wind blows at $11.8 \mathrm{~m} / \mathrm{s}$ in January).

Frequent occurrences of calm air are registered at stations in well sheltered depressions: Kragujevac $44.7 \%$, Leskovac $43.6 \%$, Kraljevo $41.6 \%$, Valjevo $40.4 \%$, whereas widely exposed northern Serbia has only a few calm intervals. Low - lying air in depressions forms "lakes" of almost flat surfaces over which winds blow undisturbed but usually weak. The rates of calms for Sjenica and Dragaš (1060 $\mathrm{m}$ a.s.l.) are $36.2 \%$ and $22 \%$, respectively.

The influence of relief on the direction and velocity of winds is prominent, because cold denser air adapts to the landforms. That is why directions of winds may be different in depressions and valleys from general directions of air currents above them. Shapes of depressions and river valley extensions are understood to be responsible for high frequencies of certain winds, as it is the case in: Banja Koviljača, Loznica, Pec, Prizren, Kraljevo, Kuršumlija, etc. In some areas (Priština, Sjenica, Zlatibor, etc.), land morphology controls two dominant "axial" directions. The above data indicate influences of meso - and micro - local climates.

\section{Inventory of Climatic Peculiarities}

There are eighty geoheritage sites protected in the Republic of Serbia. We have studied locations of these sites and the distribution of areas with peculiar local climate (see Tab. 1. and Fig. 1.) and found out that some of them coincide.

The discovered direct relationship between some landforms (canyons, gorges, plateaus) and the selected areas of peculiar

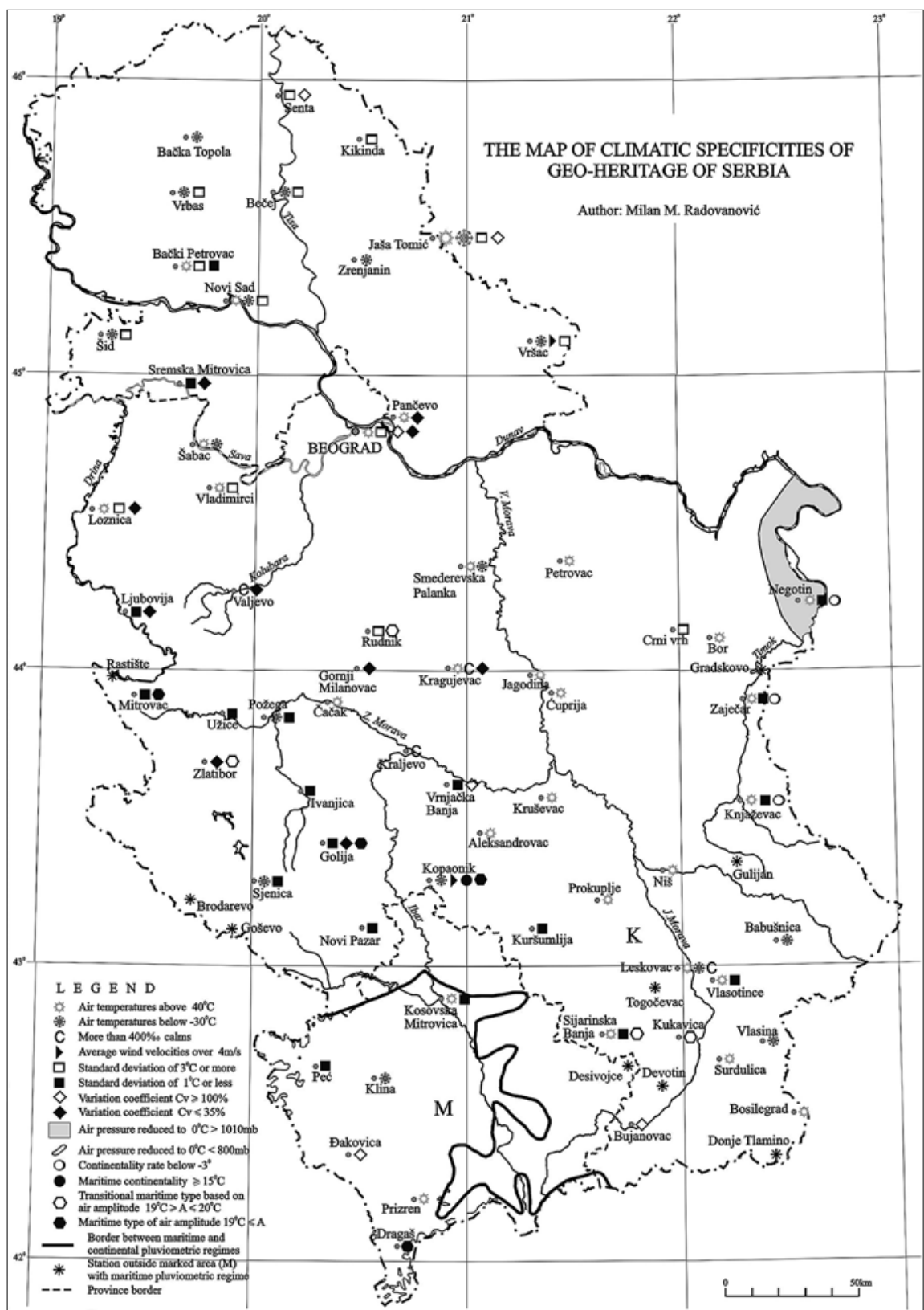

Fig. 1 The Map of climatic specificities of geo-heritage of Serbia

local climate induced us to present this paper as tentative Inventory of Climatic Peculiarities in Geoheritage Sites.

There are some objective obstacles for this Inventory:

- the network of existing stations is inadequate;

Table 1 Earth - heritage sites and climatic peculiarities

\begin{tabular}{|l|l|}
\hline Site & Observed climatic peculiarity (see map) \\
\hline Ostrovica & Rudnik \\
\hline The Vratna canyon, the Zanka canyon & Reduced air pressure area \\
\hline The Orsa source, Rugovo gorge & Peć \\
\hline The Miruša canyon & Klina \\
\hline The Mileševka gorge & Novi Pazar \\
\hline Kopaonik & Kopaonik \\
\hline The Jelašnica gorge & Niš \\
\hline Pešter & Sjenica \\
\hline Vlasina lake & Vlasina \\
\hline
\end{tabular}

- the network of pluviometric stations is the desest;

- best arranged data are those of precipitation and for areas at low altitudes;

- protected are mainly speleological sites and large landscapes; 
- incomplete inventory of geoheritage sites.

\section{Conclusion}

The relation between geoheritage sites and climatic peculiarities is a direct one. The interpolation of the latter into the former will give a new content to some geological sites, morphological features in particular, and will provide evidence of the interrelated geo - and bio - diversities. Typical examples, presented in this paper, are canyons and gorges with climatic peculiarities, which made them refuge habitats for many plant and animal, species.

In the light of the above stated, future activities should include:

- Use of the adopted analytical method in the inventory of geomorphologic sites of the Earth heritage;

- Complementation of the mentioned classification by adding "Recent environmental - climate, Holocene sedimentary geology, sedimentary events and process, morphological changes".
In addition to the described climatic peculiarities, there are other distinctions than extreme quantities that have also been observed.

\section{References}

Арманд Д. Л., 1955. Происхождение и типы природниьих границ. Известија ВГО Но 3, Москва.

Barry, R., Chorley R., 1992. Atmosphere, Weather \& Climate. Methuen \& Co. Ltd, London and New York.

Группа авторов 1985. Климаты зарубежной Европы (под редакцией Лебедева А.), Гидрометеоиздат, Ленинград.

Janković-Golubović, J. 1992. Analiza vetrova na području Srbije. Zbornik radova RHMZ, Beograd.

Radovanović, M. 2001. Uticaj reljefa i atmosferske cirkulacije na diferencijaciju klimata u Srbiji. Ph. D. thesis in manuscript. Geographical faculty, Belgrade.

Rakićević, T. 1971. Uticaj reljefa na donju granicu temperature na primeru Sjenice i Zlatibora. Zbornik radova Geografskog instituta18: 5-13.
Rakićević, T. 1976. Klimatske karakteristike istočne Srbije. Zbornik GI SANU "Jovan Cvijić" 28: 41-62.

Rakićević, T. 1979. Osnovne zakonitosti u geografskom rasporedu padavina na teritoriji SR Srbije. Zbornik radova Geografskog instituta 26: 5-18

Rakićević, T. 1988. Regionalni raspored suše u SR Srbiji. Glasnik Srpskog geografskog društva 68;9-18.

Smailagić, J., Jovanović, O. 1992. Homogenost klimatoloških nizova srednje godišnje temperature vazduha i godišnje sume padavina na glavnim meteorološkim stanicama u Srbiji. Zbornik radova RHMZ, Beograd.

Vujević, P. 1936. O stepenu kontinentalnosti mesta u Jugoslaviji Glasnik Srpskog geografskog društva 22: 30-43.

Vujević, P. 1953. Podneblje FNR Jugoslavije. Arhiv za poljoprivredne nauke12, Beograd.

Vujević, P., 1955. Razlika u visini letnjih i jesenjih padavina kao merilo njihovog maritimiteta odnosno kontinentalnosti. Zbornik GI SANU “Jovan Cvijić”: 1-14. 